\section{OUTCOME FEEDBACK:}

AN OPPORTUNITY FOR

QUALITY IMPROVEMENT

To the editor: I read with great interest Lavoie and colleagues' article regarding outcome feedback. ${ }^{1}$ I agree with the findings that most emergency physicians would like more outcome feedback. More importantly, as Lavoie states in his editorial, ${ }^{2}$ feedback on the outcomes of our decisions is vital to our becoming experts in our profession.

As a proponent of quality improvement (QI) methodology, I believe it is astounding that we have gone so far, for so long, on so little feedback. It seems emergency medicine as a profession has omitted, often by no fault of our own, the "study" component of QI's Plan, Do, Study, Act (PDSA) cycle. The use of the word "study" in this cycle emphasizes that the purpose of this phase is to build new knowledge. ${ }^{3} \mathrm{I}$ believe that outcome feedback is the "study" component of emergency medicine's improvement cycle. We assess patients (plan), provide treatment and make disposition decisions (do), then repeat this process (act) every day. However, Lavoie and colleagues' research suggests we actively get outcome feedback on our results (study) only $7.5 \%$ of the time and passively $10 \%$ of the time.

Although the company has recently been in the press for negative reasons, I doubt that Toyota, which based part of its management system on the PDSA cycle, ${ }^{4}$ would have become Canada's leader in auto maker sales rankings ${ }^{5}$ with feedback on only $17.5 \%$ of its product.

I hope to see more research in this area to emphasize the importance of this aspect of clinical practice to both our consultant colleagues and ourselves.

\section{Mark Y. Wahba, MD}

Clinical Assistant Professor and Emergency Department QI Lead, University of Saskatchewan, Saskatoon, Sask.

\section{References}

1. Lavoie C, Plint AC, Clifford TJ, et al. "I never hear what happens, even if they die": a survery of emergency physicians about outcome feedback. CJEM 2009;11:523-8.

2. Lavoie C. No news is bad news. CJEM 2009;11:566-7.

3. Langley GJ, Nolan KM, Norman CL, et al. The improvement guide: a practical approach to enhancing organizational performance. 2nd ed. San Francisco (CA): Jossey-Bass; 2009. p. 25.

4. Womack J. The machine that changed the world. Toronto (ON): Free Press; 1990. p. 291.

5. Keenan G. Toyota Canada wins sales crown. Globe and Mail Update 2009 Dec 1. Available: www.theglobeand mail.com/report-on-business/toyota -canada-wins-sales-crown/article1383969 (accessed 2009 Dec. 15).
Letters will be considered for publication if they relate to topics of interest to emergency physicians in urban, rural, community or academic settings. Letters responding to a previously published CJEM article should reach CJEM head office in Vancouver (see masthead for details) within 6 weeks of the article's publication. Letters should be limited to 400 words and 5 references. For reasons of space, letters may be edited for brevity and clarity.
Les lettres seront considérées pour publication si elles sont pertinentes à la médecine d'urgence en milieu urbain, rural, communautaire ou universitaire. Les lettres en réponse à des articles du JCMU publiés antérieurement devraient parvenir au siège social du JCMU à Vancouver (voir titre pour plus de détails) moins de six semaines après la parution de l'article en question. Les lettres ne devraient pas avoir plus de 400 mots et cinq références. Pour des raisons d'espace et par souci de concision et de clarté, certaines lettres pourraient être modifiées. 